\title{
PENGEMBANGAN SOAL HIGHER ORDER THINKING SKILLS UNTUK PENGKATEGORIAN KEMAMPUAN PEMECAHAN MASALAH GEOMETRI SISWA SMP
}

\author{
I. A. N. T. Widhiyani, I. N. Sukajaya, G. Suweken. \\ Jurusan Matematika \\ Universitas Pendidikan Ganesha \\ Singaraja, Indonesia \\ e-mail: \{dayutrisnadt@gmail.com,nyoman.sukajaya@undiksha.ac.id,gede.suweken@undiksha.ac.id\}
}

\begin{abstract}
Abstrak
Penelitian ini merupakan penelitian pengembangan yang menghasilkan suatu produk berupa soal Higher Order Thinking Skills (HOTS) berbentuk uraian untuk materi bangun ruang sisi datar. Tujuan dari penelitian ini adalah untuk mengetahui: (1) karakteristik soal yang dapat dikategorikan sebagai soal HOTS, dan (2) prosedur pengembangan kategori soal HOTS. Pemenuhan soal untuk dapat dikategoriakan sebagai soal HOTS dilihat dari karakteristik, indikator, dan langkah-langah penyusunan soal. Prosedur penelitian pengembangan ini dilaksanakan melalui beberapa tahapan yaitu tahap preliminary, self evaluation, prototyping (Validasi, Evaluasi, dan Revisi), dan uji coba lapangan (field test). Teknik analisis data pada penelitian ini meliputi uji validitas, uji reliabilitas, analisis daya beda, dan uji taraf kesukaran butir tes. Berdasarkan validasi pakar dan uji coba instrumen ke siswa diperoleh hasil : (1) 8 dari 10 soal sudah memenuhi kategori valid, (2) reliabilitas soal memiliki nilai 0,60 yang menunjukkan bahwa reliabilitas soal tinggi. (3) $50 \%$ soal termasuk kategori sedang dan $50 \%$ soal termasuk kategori sukar, dan (4) indeks daya beda soal $\geq 0,40$ dimana soal memiliki daya beda sangat baik. Hasil ini menunjukkan bahwa soal yang dikembangkan sudah baik dan memenuhi kategori soal HOTS, sehingga soal yang telah disusun dapat digunakan untuk mengukur kemampuan siswa ketika mengerjakan soal-soal HOTS.
\end{abstract}

Kata Kunci: HOTS,Kemampuan Pemecahan Masalah, Bangun Ruang Sisi Datar.

\begin{abstract}
This study is a development research which is intended to produce HOTS essay problems for solid geometry with plane surfaces. The purpose of this study is toknow : (1) the characteristics of problems which could be categorized as HOTS problems, and (2) procedures for developing the category of HOTS problems. The condition of problems in order to be categorized as HOTS problems can be viewed from the characteristics, indicators, and steps in developing the problems. The research was done through several stages, namely the preliminary stage, self evaluation, prototyping (Validation, Evaluation, and Revision), and field test. Data analysis techniques for this study consists of the validity test, reliability test, desriminating power analysis, and difficulty level of test items. Based on expert validation and field testing to students, the results are: (1) 8 of the 10 problems have met the valid category, (2) the reliability of the problems have a value of 0.60 indicating that the reliability of the problems is high. (3) $50 \%$ of the problems included in the medium category and $50 \%$ of the problems included in the difficult category, and (4) the index of descriminating power is different from the problems 0.40 where the problems had a good descriminating power. These results indicate that the developed problems are good and fulfill the HOTS problem category, so that the problems that have been prepared can be used to measure students' abilities when they were working on HOTS problems.
\end{abstract}

Keywords: HOTS, Problem Solving Ability, Solid Geometry with Plane Surface.

\section{PENDAHULUAN}

Departemen Pendidikan Nasional (2006) menyatakan bahwa tujuan pem-belajaran matematika pada jenjang pen-didikan dasar dan menengah adalah 1) memahami konsep matematika, 2) meng-gunakan penalaran pada pola dan sifat, 3) memecahkan masalah, 4) memiliki sikap dan menghargai kegunaan matematika, dan 5) mengomunikasikan gagasan di kehidupan. Pada tujuan tersebut, selain menjadi salah satu tujuan pembelajaran 
matematika pemecahan masalah juga menjadi bagian penting pada aktivitas dan aplikasi di kehidupan sehari-hari.

NCTM (2000:52) menyatakan bahwa "semua siswa harus dapat membangun pengetahuan matematika baru melalui pemecahan masalah. Hal ini dikarenakan pada proses pemecahan masalah, siswa juga dapat berusaha untuk belajar me-ngenai konsep yang belum diketahui sebelumnya, sehingga siswa dapat men-jadikan pembelajaran tersebut sebagai pengalaman belajar selanjutnya". Homles (1995) menyatakan bahwa "latar belakang seseorang perlu belajar memecahkan masalah matematika adalah adanya fakta bahwa pada abad ke-21 ini seseorang yang mampu dan terampil memecahkan masalah hidup maka mampu berpacu dengan kebutuhan hidupnya, menjadi pekerja yang lebih produktif, serta dapat memahami isu-isu kompleks yang ber-kaitan dengan masyarakat global".

Menurut Marjohan (2013:77) "pen-didikan pada abad 21 menekankan pada critical thinking dan problem solving, creativity dan innovation, communication, collaboration serta global awarness". Dari penjelasan tersebut, maka peneliti dapat katakan bahwa problem solving atau pemecahan masalah merupakan salah satu hal yang harus selalu ditekankan pada setiap aspek kehidupan manusia khususnya pada bidang pendidikan. Untuk menyelesaikan suatu permasalahan maka diperlukan nalar dan logika dalam menyelesaikannya.

Menurut Erman Suherman(2003), "matematika merupakan ilmu yang dapat melatih kemampuan berpikir dan logika seseorang". Oleh karena itu, melatih serta membiasakan siswa dalam meningkatkan kemampuan pemecahan masalahnya merupakan salah satu alternatif yang tepat untuk menghadapi pendidikan abad 21. Dengan membiasakan diri untuk me-nyelesaikan soal dengan pemecahan masalah matematika, siswa dapat melatih kemampuan berpikirnya baik dalam ber-pikir secara kritis, kreatif, maupun ber-nalar. Kemampuan pemecahan masalah matematika yaitu kemampuan seseorang untuk menemukan solusi dari suatu permasalahan non rutin dengan meng-gunakan pengetahuan, pengalaman, dan penalaran.

Kemampuan pemecahan masalah matematika dapat diperoleh siswa dengan sering menyelesaikan soal pemecahan masalah.Sehingga, pada pedidikan abad 21 kemampun pemecahan masalah siswa perlu dilatih serta diperhatikan. Selain melatih kemampuan pemecahan masalah matematika, pada pendidikan abad 21 juga diperlukan adanya perubahan cara berpikir siswa agar menjadi lebih kritis dan kreatif dalam menyelesaikan suatu per-masalahan matematika.Untuk itu siswa perlu diberikan soal-soal yang dapat memicu pemikiran siswa agar lebih kritis serta kreatif dengan cara diberikan soal-soal Higher Order Thinking Skills (HOTS).

HOTS merupakan suatu proses berpikir seseorang yang tidak hanya mampu menghafal namun mampu me-maknai suatu permasalahan yang me-merlukan analisis, ideide kreatif, meng-asosiasi hingga menarik kesimpulan dari berbagai informasi baru yang diperoleh. Adapun tujuan dari HOTS yaitu membantu siswa meningkatkan kemampuan dalam menganalisis atau memahami suatu per-masalahan berupa informasi secara lebih kritis dan kreatif dalam memperoleh hasil akhir (Dinni, 2018).

Taksonomi Bloom Revisi meng-ungkapkan bahwa kemampuan berpikir pada tingkat yang lebih tinggi melibatkan kemampuan menganalisis, mengevaluasi, dan mencipta (Anderson and Krathwohl, 2001).Adapun karakteristik-karakteristik soal HOTS(Widana, 2017)adalah sebagai berikut:

1. Mengukur kemampuan berpikir tingkat tinggi.

2. Berbasis permasalahan kontekstual.

3. Menggunakan bentuk soal beragam

Langkah-langkah penyusunan soal HOTS(Widana, 2017), yaitu:

1. Menganalisis KD yang dapat dibuat soal-soal HOTS.

2. Menyusun kisi-kisi soal.

3. Memilih stimulus yang menarik dan kontekstual.

Jurnal Pendidikan dan Pembelajaran Matematika Indonesia | 162 
4. Menulis butir pertanyaan sesuai dengan kisi-kisi soal.

5. Membuat pedoman penskoran (rubrik) atau kunci jawaban.

Terdapat beberapa penelitian yang berkaitan dengan pengembangan soal HOTS khususnya dalam pembelajaran matematika yaitu penelitian oleh Agus Budiman dan Jailani (2014), Darmawati (2017), Lestari Puji Rahayu, Ahmad Shakroni Nugroho, Muji Santoso, Suryono Widodo (2018). Diantara ketiga penelitian mengenai pengembangan soal HOTS, penelitian yang dilakukan hanya sekedar untuk mengukur kemampuan berpikir tingkat tinggi siswa pada beberapa materi dan belum ada yang melakukan penelitian dalam untuk mengetahui kemampuan pemecahan masalah matematika siswa khusus pada materi bangun ruang sisi datar.

Menurut Permendiknas No.22 Tahun 2016, mata pelajaran matematika meliputi aspek : a) bilangan, b) aljabar, c) geometri dan pengukuran, dan d) statistik dan peluang. Geometri menjadi salah satu materi wajib yang diberikan disekolah-sekolah. Sehingga berdasarkan uraian di atas, peneliti merasa perlu diadakannya penelitian tentang pengembangan soal yang dapat mengukur kemampuan siswa menyelesaikan soal HOTS. Maka dari itu, peneliti tertarik untuk mengangkat judul "Pengembangan Soal Higher Order Thinking Skills Untuk Pengkategorian Ke-mampuan Pemecahan Masalah Geometri Pada Siswa SMP".

\section{METODE}

Penelitian pengembangan dan pen-didikan ( $R$ \& $D)$ adalah proses yang di-gunakan untuk mengembangkan dan memvalidasi suatu produk pendidikan (Mangelep, 2014).Metode penelitian pengembangan terdiri dari 3 komponen utama yaitu : a) model pengembangan, b) prosedur pengembangan, dan c) uji coba produk.

\section{Model Pengembangan}

Adapun model pengembangan yang digunakan adalah dalam penelitian ini yaitutipe formative Research.

\section{Prosedur pengembangan}

Penelitian ini terdiri dari 3 tahapan yaitu (Tessmer, 1993) :

1. Tahap Preliminary

Tahap preliminary peneliti menentukan tempat dan subjek untuk melaksanakan penelitian.

2. Tahap Self Evaluation

a. Peneliti dalam hal ini melakukan analisis siswa, analisis kurikulum, dan analisis perangkat atau bahan yang dikembangkan.

b. Desain

Peneliti mendesain perangkat yang dikembangkan yang terdiri dari: kisi-kisi, tujuan, dan metode yang dikembangkan.

3. Tahap Prototyping (Validasi, Evaluasi, dan Revisi)

Produk yang telah didesain kemudian dievaluasi dengan diujicobakan kepada 3 kelompok, yaitu Expert Review, One-to-one, dan Small Group.

a) Pakar (Expert Review), yang meng-evaluasi mengenai konten, kontruks, dan bahasa.

b) One to One, produk yang telah dihasilkan diujicobakan kepada 3 siswa non subjek.

c) Kelompok Kecil (Small Group), setelah produk yang dihasilkandi-revisi, kemudian diujicobakan lagi kepada 6 siswa non subjek.

4. Tahap Uji Coba Lapangan (Field Test)

Hasil revisi dari siswa non subjek kembali diujicobakan kepada siswa yang menjadi subjek uji coba.

Alur prosedur pengembangan dapat dilihat pada gambar 1 . 


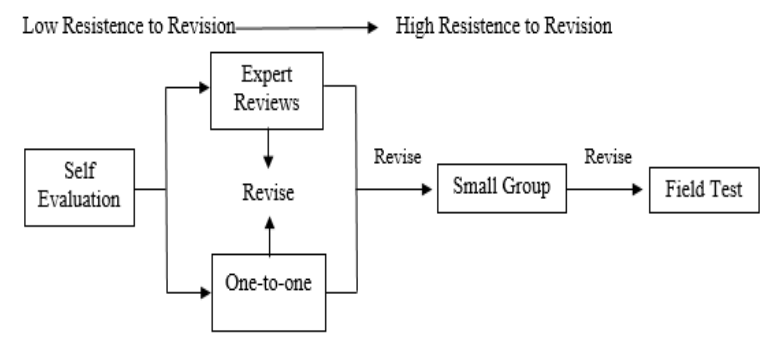

Gambar 1. Alur Prosedur Pengembangan

\section{Uji Coba Produk}

Subjek uji coba dalam penelitian pengembangan ini adalah siswa kelas VIII A dan kelas VIII F di SMP Negeri 2 Banglidengan mengambil sebanyak 47 siswa. Adapun data kuantitatif yang digunakan adalah: hasil angket yang diisi oleh validator untuk menguji validitas isi dari soal yang dikembangkan, serta hasil skor perolehan siswa setelah uji coba produk.

Teknik analisis data yang digunakan dalam penelitian ini yaitu pengujian instrumen non dikotomi meliputi pengujian validitas, reliabilitas, taraf kesukaran, daya beda, dan pengkategorian kemampuan pemecahan masalah.

a) Validitas Isi

Hasil pengujian validitas isi kepada beberapa validator kemudian di-analisis dengan menggunakan teknik Content Validity Ratio (CVR) (Lawshe,1975).

Dengan rumus : $C V R=\frac{N_{e}-\frac{N}{2}}{\frac{N}{2}}$

b) Validitas Konstruk

Pengujian validitas ini menggunakan rumus koefisien korelasi product moment.

Dengan rumus :

$$
r_{x y}=\frac{N \sum X Y-\left(\sum X\right)\left(\sum Y\right)}{\sqrt{\left\{N \sum X^{2}-\left(\sum X\right)^{2}\right)\left(N \sum Y^{2}-\left(\sum Y\right)^{2}\right\}}}
$$

c) Reliabilitas

Analisis reliabilitas instrumen tes dalam penelitian ini menggunakan rumus AlphaCronbach.

Dengan rumus :

$$
r_{11}=\left(\frac{n}{n-1}\right)\left(1-\frac{\sum \sigma_{i}^{2}}{\sum \sigma t^{2}}\right)
$$

d) Daya Beda

Indeks daya beda butir dinyatakan dengan $d$ dan dihitung menggunakan formula Ferguson.

Dengan rumus : $d=\frac{(n+1)\left(N^{2}-\sum f_{i}^{2}\right)}{n N^{2}}$

e) Taraf Kesukaran Butir

Uji taraf kesukaran butir tes objektif dilakukan dengan memperhitungkan banyak responden yang menjawab butir tersebut dengan benar.

Dengan rumus :

$I=\frac{\sum U+\sum L-\left(2 N \times S_{\min }\right)}{2 N\left(S_{\max }-S_{\text {min }}\right)}$

f) Kategori Kemampuan Pemecahan Masalah

Jurnal Pendidikan dan Pembelajaran Matematika Indonesia | 164 
Rata-rata kemampuan pemecahan masalah siswa dianalisis.

Dengan rumus: $\bar{X}=\frac{\sum_{i=1}^{n} X_{i}}{N}$

\section{HASIL DAN PEMBAHASAN}

Penelitian ini melibatkan pakar sebagai validator sebanyak 7 orang. Adapun instrumen yang dikembangkan berupa soal uraian sebanyak 11 item soal. Berdasarkan hal tersebut diperoleh data sebagai berikut.

1) Validitas Isi

Validitas isi yang dilakukan oleh 7 orang pakar menyatakan bahwa kisi-kisi dan kesesuaian item soal pada nomor 1, 2, 3, 4, 5, 6, 7, 9, 10,11 sudah sesuai. Untuk item soal nomor 8 penilaian dari 7 pakar yang ada, sebanyak 3 orang yang menyatakan soal relevan dan 4 orang lainnya menyatakan soal tidak relevan, sehingga mengakibatkan soal nomor 8 tidak sesuai. Dapat disimpulkan bahwa dari 11 item soal hanya 10 soal yang sesuai atau relevan.

2) Validitas Butir Tes

Setelah dilakukan uji coba dan dilakukan perhitungan maka diperoleh bahwa dari 10 item soal diperoleh $r_{\text {hitung }}>r_{\text {tabe }}$ sebanyak 8 item soal yang diujicobakan dikatakan valid dan diperoleh $r_{\text {hitung }}<r_{\text {tabe/sebanyak }} 2$ item soal yang diujicobakan dikatakan tidak valid.

3) Reliabilas Tes

Setelah diketahui soal yang valid, kemudian dicari reliabiltas soal, sehingga setelah dilakukan per-hitungan maka diperoleh bahwa untuk 8 item soal yang valid diperoleh nilai koefisien reliabilitas instrumen adalah0,60 dan dapat disimpulkan reliabilitas butir soal "tinggi".

4) Daya Beda Butir

Setelah diketahui soal yang valid, kemudian dicari daya beda butir soal, sehingga setelah dilakukan per-hitungan maka diperoleh bahwa semua item soal memiliki indeks daya beda butir $\geq 0,40$ yang berarti daya beda butir tergolong "sangat baik".

5) Uji Taraf Kesukaran Butir Tes

Setelah diketahui soal yang valid, kemudian dicari uji taraf kesukaran butir soal, sehingga setelah dilakukan perhitungan maka diperoleh bahwa 4 item soal yang tegolong sukar dan 4 item soal yang tergolong sedang.

6) Analisis Kemampuan Pemecahan Masalah Siswa

Hasil yang diperoleh oleh siswa kemudian dihitung untuk dapat di-lanjutkan ke tahapanpengkategorian kemampuan pemecahan masalah siswa dalam menyelesaikan soal HOTS geometri pada materi bangun ruang sisi datardiperoleh bahwa dari 127 siswa, sebanyak $17,3 \%$ siswa memiliki kemampuan pemecahan masalah pada kategori sangat tinggi, 37,8\% siswa memiliki kemampuan pemecahan masalah pada kategori tinggi,35,4\% siswa memiliki ke-mampuan pemecahan masalah pada kategori cukup, 7,9 \% siswa memiliki kemampuan pemecahan masalah kategori rendah, 1,6\% memiliki ke-mampuan pemecahan masalah pada kategori sangat rendah.

Berdasarkan hasil penelitian yang dipaparkan sebelumnya dan rumusan masalah yang aan dibahas maka perlu diketahui hal-hal yang berkaitan dengan pengembangan soal HOTS seperti apa saja karakteristik soal yang memenuhi kategori soal HOTS dan bagaimana prosedur pengembangan kategori soal HOTS. Untuk itu berikut dijelaskan mengenai karakteristik soal dan prosedur pengembangan kategori soal HOTS. 


\section{Karakteristik soal HOTS}

Karakteristik soal yang dimaksud yaitu apa saja hal-hal yang harus terpenuhi agar soal termasuk kategori soal HOTS seperti kurikulum yang digunakan, kompetensi apa yang hendak diukur, bentuk soal yang dikembangkan, danmasih banyak lagi. Dalam hal ini yang perlu diperhatikan ketika menyusun soal HOTS antara lain karakteritistik soal, indikator soal, dan langkah-langkah penyusunan soal. Untuk lebih jelasnya yaitu sebagai berikut:

Adapun karakteristik soal HOTS(Widana, 2017) adalah sebagai berikut:

- Mengukur kemampuan berpikir tingkat tinggi.

- Berbasis permasalahan konteks-tual.

- Bentuk soal beragam (dalam hal ini soal yang dikembangkan adalah soal uraian).

\section{Indikator soal HOTS}

Ranah dalam Taksonomi Bloomdigunakan untuk mengukur kemampuan berpikir tingkat tinggi seperti yang diungkap oleh Krathwohl indikator untuk mengukur kemampuan berpikir tingkat tinggi meliputi menganalisis (C4), meng-evaluasi (C5), dan mengkreasi atau mencipta (C6). Dalam hal ini, indikator soal HOTS yang dibahas yaitu hanya pada level menganalisis (C4) dan meng-evaluasi (C5). Adapun penjelasannya dari masing-masing level yaitu:

1. Level Menganalisis (C4)

Analyze (menganalisis) yaitu memisahkan materi menjadi bagian-bagian penyusunannya dan me-nentukan hubungannya, baik antar bagian maupun secara keseluruhan. Pada level menganalisis siswa lebih ditekankan pada berpikir kritis secara operasional. Level analisis terdiri dari kemampuan atau keterampilan mem-bedakan, mengorganisasikan, dan menghubungkan (Widana, 2017).

a. Differentiating (membedakan) terjadi ketika siswa mem-bedakan bagian yang tidak relevan dan yang relevan atau dari bagian yang penting ke bagian yang tidak penting dari suatu materi yang diberikan.

b. Organizing (mengorganisasikan) menentukan bagaimana suatu bagian elemen tersebut cocokdan dapat berfungsi bersama-sama di dalam suatu struktur.

c. Attributing (menghubungkan) terjadi ketika siswa dapat me-nentukan inti atau menggaris bawahi suatu materi yang di-berikan.

Kata Kerja Operasional yang digunakan yaitu mem-bandingkan,mengkritisi mengurutkan, membedakan, dan menentukan.

2. Level Mengevaluasi (C5)

Evaluate (mengevaluasi) yaitu membuat keputusan berdasarkan kriteria yang standar, seperti mengecek dan mengkritik.

a. Cheking (mengecek)

terjadi ketika siswa mengecek ketidakkonsistenan proses atau hasil, menentukan proses atau hasil yang memiliki ke-konsistenan internal suatu prosedur yang diterapkan.

b. Critiquing (mengkritisi)

terjadi ketika siswa mendeteksi hasil dan beberapa kriteria luas atau keputusan yang sesuai dengan prosedur masalah yang diberikan.

Kata Kerja Operasional yang digunakan yaitu meng-evaluasi, memilih/menyeleksi, menilai,menyanggah, mem-berikan pendapat.

\section{Langkah-langkah penyusunan soal HOTS}

Dalam penyusunan soal HOTS, dibutuhkan penguasaan materi ajar, ke-terampilan dalam menulis soal (konstruksi soal), dan kreativitas guru dalam memilih stimulus soal. Selain yang disebutkan di atas, dipaparkanlangkah penyususnan soal HOTS(Widana, 2017), yaitu:

1. Menganalisis KD yang dapat dibuat soal-soal HOTS

Jurnal Pendidikan dan Pembelajaran Matematika Indonesia | 166 
Terlebih dahulu guru-guru memilih KD yang dapat dibuatkan soal-soal HOTS. Tidak semua KD dapat di-buatkan model-model soal HOTS. Guru-guru secara mandiri atau forum MGMP dapat melakukan analisis terhadap KD yang dapat dibuatkan soal-soal HOTS.

2. Menyusun kisi-kisi soal

Kisi-kisi penulisan soal-soal HOTS bertujuan untuk membantu para guru dalam menulis butir soal HOTS. Secara umum, kisi-kisi tersebut diperlukan untuk me-mandu guru dalam (a) memilih KD yang dapat dibuat soal-soalHOTS, (b) memilih materi pokok yang terkait dengan KD yang diuji, (c) merumuskan indikator soal, dan (d) menentukan level kognitif.

3. Memilih stimulus yang menarik dan kontekstual.

Stimulus yang digunakan hendak-nya menarik, artinya mendorong peserta didik untuk membaca. Sedangkan stimulus kontekstual berarti stimulus yang sesuai dengan kenyataan dan mendorong peserta didik untuk membaca. Dalam konteks ujian sekolah, guru dapat memilih stimulus dari lingkungan sekolah atau daerah setempat.

4. Menulis butir pertanyaan sesuai dengan kisi-kisi soal.

Kaidah penulisan butir soal HOTS, agak berbeda dengan kaidah penulisan butir soal pada umum-nya. Perbedaannya terletak pada aspek materi, sedangkan pada aspek konstruksi dan bahasa relatif sama.

5. Membuat pedoman penskoran (rubrik) atau kunci jawaban

Butirsoal HOTS yang ditulis hendaknya dilengkapi dengan pedoman penskoran atau kunci jawaban. Pedoman penskoran dibuat untuk bentuk soal uraian. Sedangkan kunci jawaban dibuat untuk bentuk soal pilihan ganda, pilihan ganda kompleks (ya/tidak), (benar/salah), dan isian singkat.

\section{Prosedur Pengembangan}

Masing-masing penelitian memiliki metode penelitian yang berbeda-beda. Menurut Sugiyono (2007: 297), metode penelitian dan pengembangan adalah metode penelitian yang digunakan untuk menghasilkan produk tertentu, dan menguji keefektifan produk tersebut. Prosedur pengembangan suatu produkberupa soal HOTS dalam hal ini sesuai dengan gambar 1. Sehingga berikut hanya dijelaskan tahapan-tahapan yang perlu dilaksanakan untuk mengembangkan suatu produk, adapun penjelasan dari masing-masing tahapan yaitu:

1. Tahap Preliminary

Tahap Preliminary dilakukan peng-kajian terhadap beberapa sumber referensi yang berkaitan dengan penelitian ini. Pada tahap ini, peneliti menentukan tempat dan subjek penelitian seperti dengan cara meng-hubungi kepala sekolah dan guru mata pelajaran disekolah yang menjadi lokasi penelitian untuk memperoleh informasi mengenai kemampuan siswa secara umum dalam mengikuti kegiatan pembelajaran. Selanjutnya peneliti mengadakan persiapanlainnya, seperti mengatur jadwal penelitian dan prosedur kerja-sama dengan wali kelas yang di-jadikan tempat penelitian.

2. Tahap Self Evaluation

a) Tahap ini merupakan langkah awal penelitian pengembangan. Peneliti dalam hal ini melakukan analisis siswa, analisis kurikulum, dan analisis perangkat atau bahan yang dikembangkan.

b) Desain

Pada tahap ini peneliti mendesain perangkat yang dikembangkan yang meliputi pendesainan kisi-kisi, tujuan, dan metode yang di-kembangkan.

1. Menyusun kisi-kisi soal

Menyusunan kisi-kisi soal HOTS untuk membantu dalam menulis butir soal. Adapun langkah-langkah dalam menyusun kisi-kisi yaitu: (a) menentukan KD yang dapat dibuat soal-soal HOTS, (b) memilih materi pokok yang terkait dengan KD yang diuji, (c) merumuskan indikator soal, serta (d) memenentukan level kognitif. 
2. Menulis butir pertanyaan sesuai dengan kisi-kisi soal.

Butir-butir pertanyaan ditulis sesuai dengan kaidah penulisan butir soal HOTS. Kaidah pe-nulisan butir soal HOTS sedikit berbeda dengan kaidah pe-nulisan butir soal pada umum-nya. Perbedaannya terletak pada aspek materi, sedangkan pada aspek konstruksi dan bahasa relatif sama.

3. Membuat pedoman penskoran (rubrik) atau kunci jawaban.Setiap butir soal yang ditulis hendaknya dilengkapi dengan pedoman penskoran atau kunci jawaban.

3. Tahap Prototyping (Validasi, Evaluasi, dan Revisi)

Pada tahap ini produk yang telah dibuat atau didesain kemudian dievaluasi. Tahap evaluasi ini produk diujicobakan dalam 3 kelompok. Hasil desain pada prototypepertama yang dikembangkan atas dasar self evaluation diberikan pada pakar (Expert Review), siswa (One-to-one) dan small group secara paralel.

a. Pakar (Expert Review)

Expert Review adalah teknik untuk memperoleh masukan atau saran dari para ahli untuk pe-nyempurnaan instrumen tes. Pada tahap uji coba pakar (expert review) disini atau biasanya disebut uji validitas, produk yang telah didesain kemudian dicermati, dinilai dan dievaluasi oleh pakar atau ahli. Para pakar atau validator menelaah konten, konstruks dan bahasa dari masing-masing prototype.

Berdasarkan hasil validasi dari validator penelitikemudian dilakukan analisis terhadap hasil tersebut. Jika hasil analisis menunjukkan:

(a) Valid tanpa revisi, maka kegiatan selanjutnya adalah field test;

(b) Valid dengan ada revisi, maka kegiatan selanjutnya adalah merevisi terlebihdahulu, kemudian langsung field test

(c) Tidak valid, maka dilakukan revisi sehingga diperoleh prototype baru, kemudiankembali pada kegiatan expert review atau penilaian ahli.

Pada tahap ini, tanggapan dan saran dari para validator tentang desain yang telah ditulis pada lembar validasi sebagai bahan me-revisi danmenyatakan bahwa instrumen tes kemampuan berpikir tingkat tinggi tersebut telah valid.

b. One to One

Pada tahap ini, peneliti me-manfaatkan 3 orang siswa sebaya non subjek uji coba sebagai tester. Ketiga siswa yang menjadi tester terbagi menjadi 3 yakni siswa dengan kemampuan rendah, siswa dengan kemampuan sedang, dan siswa dengan kemampuan tinggi. Berdasarkan komentar ketiga siswa tersebut desain produk yang telah dibuat, direvisi dan diperbaiki.

c. Kelompok Kecil (Small Group)

Hasil revisi dari expert dan saran di one-to-one pada prototype per-tama dijadikan dasar untuk merevisi desain prototype kedua. Pada tahap ini dilakukan uji coba pada kelompok kecil terdiri dari 6 orang, karakteristik siswa terdiri dari dua siswa dengan kemampuan tinggi, dua siswa dengan kemampuan sedang dan dua siswa dengan kemampuan rendah. Berdasarkan hasil tes dan tanggapan siswa inilah soal direvisi dan diperbaiki lagi. Hasil tahap ini diharapkan menghasilkan instrument yang mampu mengukur kemampuan berpikir tingkat tinggi siswa.

d. Tahap Uji Coba Lapangan (Field Test)

Pada tahap ini komentar atau saran-saran serta hasil uji coba pada prototype pertama dijadikan dasar untuk merevisi desain prototype pertama. Hasil revisidiujicobakan ke subjek penelitian dalam hal ini sebagai field test. Uji coba pada tahapini produk yang direvisi tadi diujicobakan kepada siswa yang menjadi subjek uji coba. Selanjutnya data yang diperolehdari uji coba tahap ini (field test) dianalisis reliabilitas, tingkat kesukaran,dan dayapembedanya.Bila memenuhi kriteria tes maka dilanjutkan ke tahap selanjutnya.Jika tidak, maka dilakukan revisi dan uji lapangan (field test) kembali, sehinggadidapatkan final prototype yang sesuai dengan kriteria yang diinginkan 


\section{SIMPULAN DAN SARAN}

Berdasarkan rumusan masalah, tujuan, hasil analisis, dan pembahasan yang telah diuraikan di depan, dapat disimpulkan bahwa:

1. Setelah dilakukan uji validitas, uji reliabilitas, analisis daya beda, dan uji taraf kesukaran butir maka diperoleh hasil yaitu soal yang dikembangkan sebanyak 8 butir soal yang memiliki reliabilitas tinggi, daya beda butir soal yang baik, dan uji taraf kesukaran soal sedang dan sukar. Sehingga dapat dikatakan bahwa soal yang di-kembangkan sudah sesuai.

2. Dalam mengembangkan suatu produk contohnya soal HOTS maka perlu diperhatikan apa saja karakteristik yang memenuhi kategori soal HOTS seperti:
a) Karakteristik soal HOTS
b) Indikator soal HOTS
c) Langkah-langkah penyusunan soal HOTS.

3. Terdapat beberapa tahapan dalam prosedur pengembangan kategori soal HOTS yaitu sebagai berikut:
a) Tahap Preliminary
b) Tahap Self Evaluation
c) Tahap Prototyping(Validasi, Evaluasi, dan Revisi)
d) Tahap Uji Coba Lapangan (Field Test)

Adapun saran yang ingin disampaikan yaitu:

1. Untuk sekolah-sekolah khusunya para guru yang mengampu mata pelajaran matematika, sebaiknya siswa mulai dibiasakan untuk menyelesaikan tipe soal HOTS, sebab beberapa soal UN merupakan soal HOTS. Sehingga melatih siswa mengerjakan soal-soal HOTS diharapkan dapat membantu siswa nantinya.

2. Bagi guru pembina olimpiade matematika, soal yang dikembangkan dapat digunakan sebagai tes bagi siswa yang ingin mengikuti klub atau bagi siswa yang mengikuti olimpiadeagar dapat mengukur sejauh mana kemampuan yang dimiliki oleh siswa.

3. Bagi yang ingin mengembangkan soal HOTS, dapat dikaji kembali materi-materi yang dapat memenuhi kategori soal HOTS baik pada jenjang SD, SMP, maupun SMA sebab masihjarang orang yang mengembangkan soal tipe HOTS.

\section{Daftar Pustaka}

Penulisan daftar pustaka terdiri-dari nama penulis, tahun penerbitan, judul artikel, nama kota dan institusi penerbitan. Daftar rujukan diurutkan sesuai huruf pertama nama penulis (AZ). Kata kedua dalam nama disepakati sebagai nama keluarga. Semua pustaka yang dirujuk dalam teks harus dituliskan dalam daftar rujukan. Daftar rujukan diutamakan merupakan artikel yang diambil dari jurnal / publikasi terbaru paling lama 5 tahun sebelum pengiriman artikel (paper submission). Cara penulisan rujukan: nama keluarga dan tahun (Pitunov, 2007)

Ary, D., Jacobs, L.C. \& Razavieh, A. 1976. Pengantar Penelitian Pendidikan. Terjemahan oleh Arief Furchan. 1982. Surabaya: Usaha nasional

Arikunto, S. 1998. Prosedur Penelitian. Jakarta: Rinneka Cipta

Jawa Pos. 22 April 2008. Wanita Kelas Bawah Lebih Mandiri, hlm. 3

Kansil, C.L. 2002. Orientasi Baru Penyelenggaraan Pendidikan Program Profesional dalam Memenuhi Kebutuhan Dunia Idustri. Transpor, XX(4): 54-5 (4): 57-61

Kumaidi. 2005. Pengukuran Bekal Awal Belajar dan Pengembangan Tesnya. Jurnal IImu Pendidikan. Jilid 5, No. 4, 
Kuntoro, T. 2006. Pengembangan Kurikulum Pelatihan Magang di STM Nasional Semarang: Suatu Studi Berdasarkan Dunia Usaha. Tesis tidak diterbitkan. Semarang: PPS UNNES

Pitunov, B. 13 Desember 2007. Sekolah Unggulan Ataukah Sekolah Pengunggulan ? Majapahit Pos, hlm. 4 \& 11

Waseso, M.G. 2001. Isi dan Format Jurnal IImiah. Makalah disajikan dalam Seminar Lokakarya Penulisan artikel dan Pengelolaan jurnal IImiah, Universitas Lambungmangkurat, 9-11Agustus 